\title{
GEOLOGIC MAP SHOWING PART OF THE MAY CREEK SCHIST AND RELATED ROCKS, JACKSON COUNTY, OREGON
}

\author{
By \\ Mary M. Donato
}

\section{REGIONAL SETTING}

The metamorphic rocks shown on the accompanying geologic map occupy the northeasternmost part of the Klamath Mountains Province and are in fault contact to the east with Tertiary rocks of the Western Cascades Province. Two of the four lithotectonic belts of the Klamath Mountains Province as defined by Irwin (1966) are represented in the mapped area: the western Paleozoic and Triassic belt and the western Jurassic belt (fig. 1). Although Irwin's (1966) nomenclature is still in use, readers should note that these names do not accurately reflect the currently regarded ages of these units. The tectonostratigraphic terrane terminology used in this report has been widely adopted. Rocks in this part of the western Paleozoic and Triassic belt consist of rocks commonly referred to as the May Creek terrane and the Applegate terrane (Silberling and others, 1987; Irwin, in press). The westernmost part of the mapped area, part of
Irwin's (1966) western Jurassic belt, includes rocks belonging to Silberling and others' (1987) Rogue Valley subterrane of the western Klamath terrane.

The western Paleozoic and Triassic belt is a complex collage of metamorphosed accreted oceanic and island arc material that spans the entire length of the Klamath Mountains in southwestern Oregon and northern California. In southwestern Oregon, the rocks of the western Paleozoic and Triassic belt are known as the Applegate Group, an extensive unit that includes a wide variety of volcanic, sedimentary, and crystalline rocks. These rocks were originally described, but not named, by Diller (1914), who believed that they were Devonian and Carboniferous in age on the basis of poorly preserved fossils in limestone. The rocks were later named the Applegate Group by Wells and others (1949), who assigned them a Triassic(?) age. Later reconsideration of fossil collections caused the age of the Applegate to be revised to Late(?) Triassic (Wells and Peck, 1961). Still



EXPLANATION



Western Jurassic belt

Western Paleozoic and

Triassic belt

Figure 1. Generalized geologic map of northern part of Klamath Mountains Province. 
later revision of the age of the Applegate to Late(?) Triassic and Jurassic by Wardlaw and Jones (1979) was based on Jurassic radiolarians from the western part of the Applegate Group as reported by Irwin and others (1978).

The western Jurassic belt in this area consists of greenschist-facies volcanic, volcaniclastic, and sedimentary rocks considered to be lithic equivalents of the Jurassic Rogue Formation and an assemblage of basaltic, gabbroic, and ultramafic rocks called the ophiolite of Sexton Mountain area by Smith and others (1982).

Two postmetamorphic plutons intrude the western part of the May Creek Schist and underlying amphibolite, and extensive weathering limits exposures in all but a few localities. Contact metamorphism by the White Rock pluton (141 Ma, biotite K-Ar, Hotz, 1971) extends a few hundred feet into the surrounding amphibolite. The Wimer pluton intrudes both the May Creek Schist and the amphibolite, but isotopic age determinations for this pluton are not presently available. These two plutons, along with the nearby Grants Pass pluton (139 Ma, U-Pb, zircon, Saleeby, 1984) belong to Irwin's (1985) Early Cretaceous Grants Pass (plutonic) belt.

An outlier of Lower Cretaceous sedimentary rocks equivalent to the Grave Creek strata of Jones (1960) and belonging to the Hornbrook Formation constitutes the northernmost patch of a southeast-trending discontinuous belt of conglomerate, sandstone, and siltstone that overlaps pre-Cretaceous rocks of the Klamath Mountains and extends into northern California (Sliter and others, 1984).

\section{MAY CREEK SCHIST}

\section{CORRELATION AND DISTRIBUTION}

Mica schist and mica slate considered to be Devonian(?) in age and located near the town of Wimer, Oregon, were named the May Creek Formation by Diller and Kay (1924). Subsequently, Wells and Waters (1934) applied the name "May Creek Schist" to contiguous rocks found immediately to the east in the Meadows Mining District. More recent workers have used the name "May Creek" to encompass schist and amphibolite as far north as the Umpqua River (see Kays, 1970; Smith and others, 1982; Donato, 1987). In this report, this unit is everywhere renamed the May Creek Schist in order to better define its lithology; it is also revised to consist of most of Wells and Waters' (1934) and Diller and Kay's (1924) May Creek rocks, the older metarhyolite unit of Diller and Kay (1924), and part of the greenstone, gabbro, and related rocks unit of Diller and Kay (1924). The distribution of the May Creek Schist as used in this report is shown in figure 2. The May Creek Schist of the present study corresponds, in part, to metasedimentary unit Ps of Smith and others (1982), but does not include those rocks north of about $42^{\circ} 37^{\prime} 30^{\prime \prime} \mathrm{N}$., and thus excludes metasedimentary and metavolcanic rocks of uncertain correlation exposed northeast of the White Rock pluton (unit Jmsu, this report). A small exposure of the May Creek Schist is also mapped at the northwest contact of the Wimer pluton, but these rocks comprise only part of the area mapped as unit Pss by Smith and others (1982).

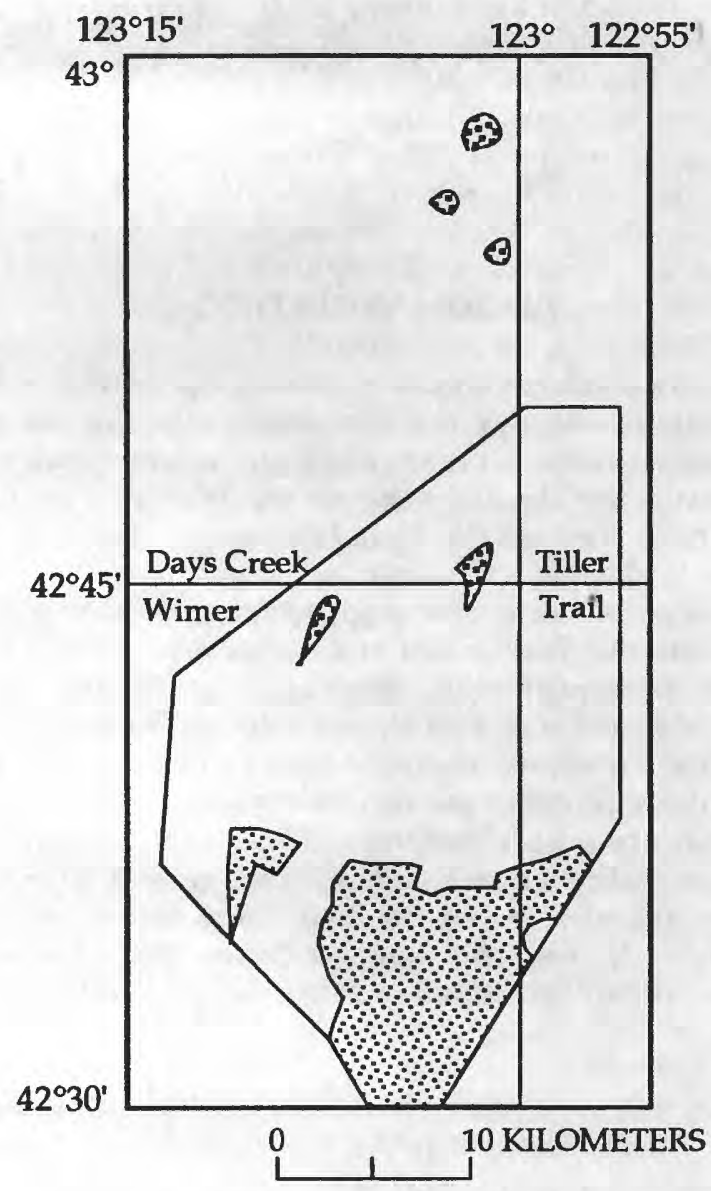

\section{EXPLANATION}

May Creek Schist of this report

Exposures previously mapped as May Creek Formation by Diller and Kay (1924) and excluded from the May Creek Schist in this report

Figure 2. Sketch map showing distribution of May Creek Schist as used in this report. Names of $1^{\prime}$ quadrangles in Oregon shown.

The south limit of the May Creek Schist is not certain. No abrupt changes in metamorphic grade, lithology, or structural style were observed within the southern part of the map area, suggesting that the May Creek Schist may extend farther south than has been mapped heretofore. Reconnaissance mapping indicates tinat amphibolitefacies rocks lithologically resembling the May Creek Schist, including strongly deformed volcanogenic metasedimentary rocks, are found along the banks of the Rogue River in the town of Gold Hill, at the mouth of Sardine Creek, and near Rock Point, about $8 \mathrm{~km}$ south of the south map boundary. They are crosscut by undeformed greenschist-facies hornblende-phyric dikes whose age and genesis are presently unknown. 
The May Creek Schist was considered to be part of the Applegate Group by Wells and others (1949). More recent mapping in this region (Kays, 1970; Page and others, 1977; Smith and others, 1982; this study) indicates that, on the basis of lithologic and metamorphic evidence, both the May Creek Schist and the structurally underlying amphibolite should no longer be considered as part of the Applegate Group. The May Creek Schist in the mapped area consists exclusively of metasedimentary rocks; no metamorphosed primary volcanic rocks (for example, flows) were recognized, although volcaniclastic rocks are abundant in the southern part of the mapped area. The amphibolite consists of mineralogically and chemically homogeneous metaigneous rocks with little or no identifiable volcaniclastic component. In contrast, the Applegate Group $25 \mathrm{~km}$ to the south consists of dacitic, andesitic, and basaltic flow material as well as a wide variety of interlayered volcaniclastic rocks, chert, and limestone (Wells, 1955; Blair and others, 1981; Smith and others, 1982). There is no clear separation of sedimentary and igneous components as there is between the May Creek Schist and the amphibolite.

Both the May Creek Schist and the amphibolite contain metamorphic mineral assemblages indicating middle-amphibolite-facies metamorphic grade. Both units possess parallel (and presumably contemporaneous) foliations, lineations, and fold axes. Their mutual contact is a high-temperature ductile shear zone, in which stretching lineations are parallel to hornblende lineations throughout the underlying amphibolite. Therefore, both units probably underwent synchronous metamorphism and ductile deformation, events which culminated with overthrusting of the May Creek Schist (Donato, 1990). In contrast, the regional metamorphic grade of the Applegate Group seldom exceeds greenschist facies and appears to be uniformly low except near contacts with younger plutons.

On the basis of these important lithologic and metamorphic distinctions, both the May Creek Schist and the underlying amphibolite are here restricted from the Applegate Group. Together, these two units form the May Creek terrane of Silberling and others (1987) and Irwin (in press).

\section{AGE}

There are at present no direct determinations of either the metamorphic or protolith age of the May Creek Schist. However, on the basis of the apparent cometamorphic character of the amphibolite and the May Creek Schist as discussed above, it may be inferred that the metamorphic age of the May Creek Schist is the same as that of the amphibolite. Two new ${ }^{40} \mathrm{Ar} /{ }^{39} \mathrm{Ar}$ age determinations on hornblende from the amphibolite directly underlying the May Creek Schist yielded Late Jurassic metamorphic ages (see below); therefore the metamorphic age of the May Creek Schist is also considered to be Late Jurassic. These ages are coeval with the age of the Nevadan orogeny in this region (Harper and Wright, 1984). The protolith age of the May Creek Schist is considered to be Jurassic or older.

\section{AMPHIBOLITE}

\section{LITHOLOGY}

The unnamed amphibolite that structurally underlies the May Creek Schist consists primarily of dark-greenishgray to black, well-foliated and lineated hornblendeplagioclase schist or gneiss. Metamorphic segregation banding is generally weakly developed, and the foliation is commonly defined by planar arrangement of clusters of hornblende or flattened plagioclase grains. Although most of the amphibolite is strongly deformed, textures indicating igneous protoliths are preserved locally in lessdeformed rocks, thorough metamorphic recrystallization notwithstanding.

In addition to the abundant "common" amphibolite (amphibole schist), three textural varieties of amphibolite were recognized: metaporphyry, metadiorite, metagabbro, (named for their apparent igneous protoliths) as well as a dark-colored amphibolite associated with metaserpentinite bodies (not shown on the geologic map). These varieties have essentially the same component mineralogies as the common amphibolite: hornblende+plagioclase+accessory sphene $\pm \mathrm{Fe}-\mathrm{Ti}$ oxide.

Metaporphyry, which is found as weakly foliated dikeor sill-shaped bodies about $30 \mathrm{~cm}$ to $1 \mathrm{~m}$ thick, displays striking examples of relict igneous textures. It commonly contains as much as 10 percent plagioclase laths and blocky hornblende pseudomorphs replacing pyroxene. These minerals commonly are not aligned in the foliation plane, and are observed in a variety of sizes and shapes as long as $1 \mathrm{~cm}$. In some cases lamellar twinning is still present in plagioclase. These minerals are interpreted as relict igneous phenocrysts. In many cases, sharp concordant or subconcordant boundaries between multiple porphyritic and aphyric layers suggest intrusive contacts between sheeted dikes or sills. Decreasing grain size outward toward the contacts suggests chilled margins. In rare instances, metamorphosed dikes crosscut one another at a low angle, and close observation indicates that the contacts were translated into parallelism with the local foliation, indicating that multiple intrusive episodes occurred prior to latest foliation development. Good examples of metaporphyry can be seen in outcrops in the West Fork of Evans Creek near the Salt Creek Guard Station site.

Metagabbro forms coarse-grained (grain size greater than or equal to $1 \mathrm{~cm}$ ), massive to foliated, concordant tabular bodies ranging in thickness from 1 to $4 \mathrm{~m}$. Grain size is commonly variable within a single outcrop, and the coarsest grained massive varieties (grain size as large as 2 $\mathrm{cm}$ ) have the appearance of gabbroic pegmatite. Some of the larger hornblende grains contain clinopyroxene cores.

Metadiabase is characterized by interlocking, unaligned prismatic hornblende with interstitial plagioclase. Its texture strongly resembles diabasic textures common in shallow basaltic intrusive rocks. Although no metadiabase contact relations were observed, the abundance of this variety suggests that sills, dikes, and probably even small plutons were important components of the protoliths of the amphibolite.

Metaserpentinite bodies ranging from a few meters to almost $1 \mathrm{~km}$ in largest dimension are concordantly 
interlayered with the amphibolite and are particularly abundant near the ductile shear zone. Isofacial mineral assemblages in the serpentinite indicate that it was metamorphosed along with the surrounding amphibolite. They are interpreted as tectonic slices of upper-mantle material that were incorporated into the section prior to or during the peak metamorphic event.

Amphibolite lenses partly or completely enclosed by such metaserpentinite bodies are common and display a wide range of textures and mineralogies. This type of amphibolite is inferred to be tectonically emplaced fragments of basaltic material mixed into the serpentinite during its ascent to midcrustal or upper-crustal levels. In most cases a few-cm-wide rind of "blackwall" (Mgmetasomatic rock developed during metamorphism) composed of chlorite, talc, and in some cases, tremolite, is present at the fault contact with serpentinite. Hornblende in this type of amphibolite is commonly brown instead of green, and one sample contains the assemblage brown hornblende+plagioclase+clinopyroxene, suggesting slightly higher metamorphic grade. Although most samples of this type show no relict igneous features, the texture of one sample suggests a cumulate igneous protolith.

\section{GEOCHEMISTRY}

Approximately 30 samples of amphibolite were chemically analyzed for major and trace elements, including rare-earth elements (REE), to characterize the tectonic setting of eruption or intrusion of the igneous protolith of this unit. The chemistry indicates that some alteration of the original basaltic compositions has probably occurred, either on the sea floor, or during regional metamorphism, or both. Nevertheless, certain elements were relatively immobile (for example, $\mathrm{Ti}, \mathrm{Zr}, \mathrm{Y}$, $\mathrm{Cr}, \mathrm{Th}$, and the light rare-earth elements) and probably retain their original igneous abundances (Donato, 1987; in press). Numerous tectonic discrimination plots (for example, Pearce and Cann, 1973; Wood, 1980; Pearce and Norry, 1979; and Hawkins, 1980) highlight the amphibolite's similarity to midocean ridge basalts (MORB), but enrichment in elements such as Th and the light REE relative to MORB suggest that a back-arc basin was a more likely environment for the genesis of these rocks. This chemical enrichment is attributed to the influence of enriched hydrothermal fluids from a subducting slab on the overlying mantle wedge beneath the back-arc basin (Saunders and Tarney 1979; Sinton and Fryer 1987; Jenner and others, 1987).

\section{AGE}

${ }^{40} \mathrm{Ar} /{ }^{39} \mathrm{Ar}$ total fusion experiments on hornblende mineral separates from 2 samples of amphibolite yield metamorphic ages of $145 \pm 2 \mathrm{Ma}$ and $145 \pm 7 \mathrm{Ma}$ (Donato, in press). Sample localities are shown on the accompanying map. The protolith age of the amphibolite is considered to be Jurassic or older.

\section{REGIONAL METAMORPHISM}

Metamorphic grade in the map area ranges from greenschist facies to amphibolite facies. No regional metamorphic gradients were observed; most changes in metamorphic grade are abrupt and coincide with faults (fig. 3). A possible exception is found at the queried fault contact between the amphibolite and mafic schist (units am and Jmsu), where poor exposures and contact metamorphism prevented the relation between those two units to be clearly understood. A metamorphic gradient from amphibolite facies to greenschist facies may exist in this area.

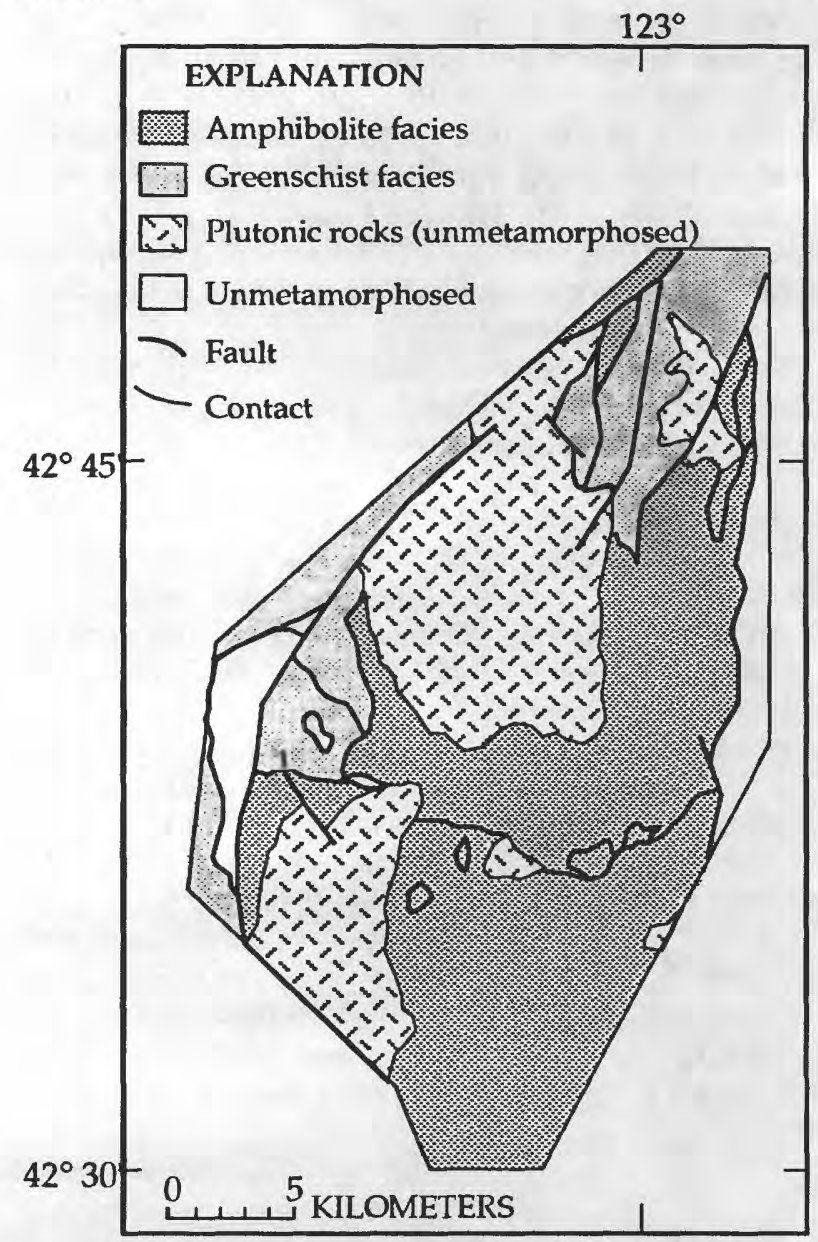

Figure 3. Metamorphic-facies map of May Creek Schist and adjacent rocks in area of this report. Faults and contacts are approximately located.

The metamorphic grade of the May Creek Schist is uniformly amphibolite facies, on the basis of mineral assemblages in pelitic, calcareous, and intermediate volcaniclastic compositions. Most pelitic schists contain quartz, plagioclase, biotite, white mica, and in some cases, garnet. Tourmaline and an opaque mineral (ilmenite?) are common accessories. Altered porphyroblasts composed of fine micaceous material were found in several samples. They could once have been staurolite or aluminosilicate, but no vestiges of those minerals were found. Sillimanite was found in two localities: in ductilely deformed metapelite east of Sprignett Creek and in metapelite from the ridge north of Raspberry Creek (a 
thin unmapped metapelitic interval within the amphibolite unit). Attempts to determine metamorphic temperatures in 4 samples (see map for sample localities) using garnet-biotite geothermometry yielded variable results. For 3 of the samples, most temperatures ranged from around $540^{\circ} \mathrm{C}$ to just below $700^{\circ} \mathrm{C}$ using the Hodges

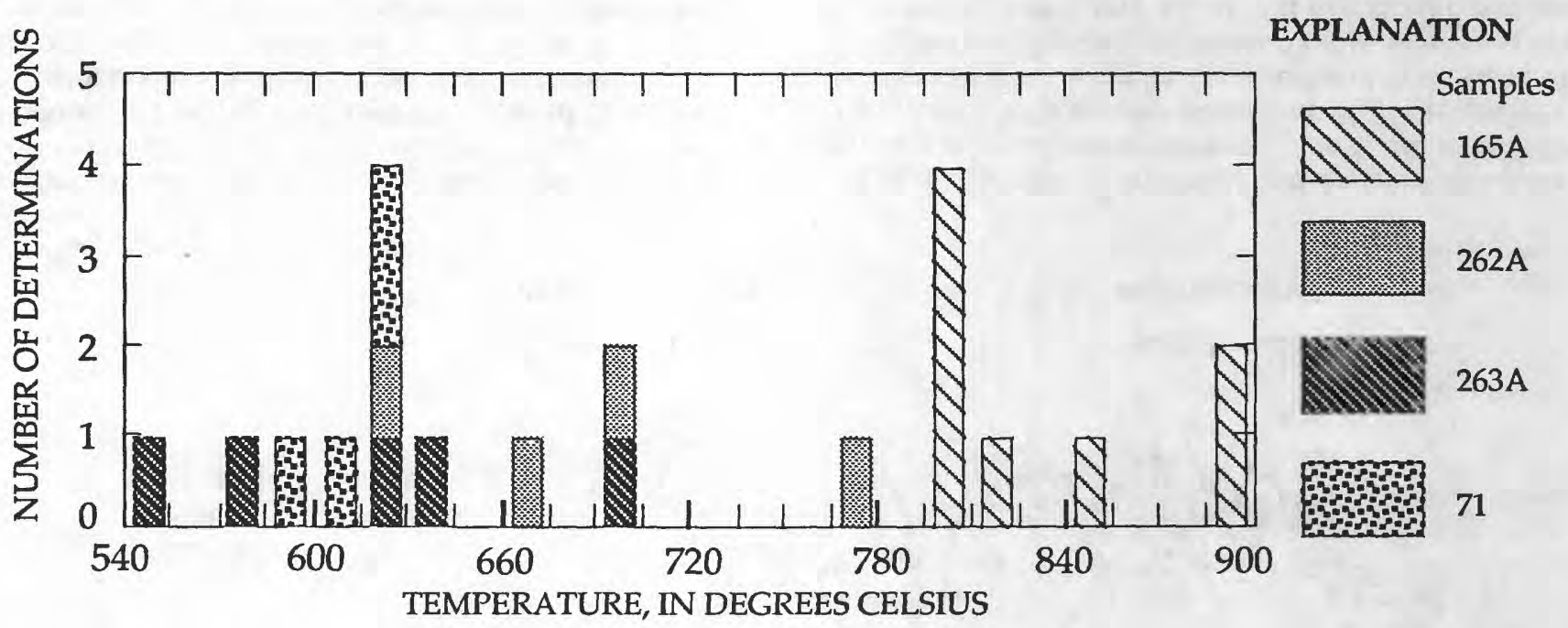

Figure 4. Garnet-biotite metamorphic temperatures determined for 4 samples of metapelitic rocks from May Creek Schist. Calibration of Hodges and Spear (1982) was used and pressure of $5 \mathrm{~kb}$ was assumed. See map for sample localities.

and Spear (1982) calibration and an assumed pressure of $5 \mathrm{~kb}$ (fig. 4). One sample (165A) yielded unrealistically high temperatures (about $795^{\circ} \mathrm{C}$ to nearly $900^{\circ} \mathrm{C}$ ), probably because the calcium content of the garnet is exceedingly high (as great as $5.8 \mathrm{wt}$. percent $\mathrm{CaO}$ ). Calcareous and marly intervals in the May Creek Schist develop diopside, epidote, microcline, and sphene along with calcite, quartz, and amphibole (actinolite and hornblende). The assemblage in volcaniclastic lithologies of the May Creek Schist is hornblende, plagioclase, sphene, and in some cases, epidote. The presence of epidote seems to be related to bulk composition rather than to metamorphic grade.

The mineral assemblage in the amphibolite is uniform and simple: hornblende, plagioclase, sphene (or rutile), and opaque oxide. Epidote is present only rarely and may be developed in former flows that had undergone sea-floor alteration (epidotization) prior to regional metamorphism. Neither chlorite nor garnet were present in equilibrium assemblages.

A single sample of metamorphosed serpentinite from Sprignett Creek contains the assemblage olivine+clinopyroxene+orthopyroxene+chlorite+green spinel+opaque. This assemblage indicates pyroxene hornfels or granulite facies metamorphic grade, higher temperatures than were found elsewhere in the study area. The origin of this unusually high-grade metaserpentinite is not known. Its location near the thrust fault between the amphibolite and the May Creek Schist suggests it may not have been metamorphosed in situ.

In summary, the mineral parageneses in the May Creek Schist and in the amphibolite point to middleamphibolite-facies conditions. In contrast, rocks of the adjacent Applegate Group range from lower greenschist facies to lower amphibolite facies (Blair and others, 1981) and are generally less thoroughly recrystallized and less penetratively deformed. The nearest rocks of similar grade and degree of recrystallization to the May Creek Schist belong to the (informal) Briggs Creek amphibolite of Garcia (1979), about $50 \mathrm{~km}$ to the west. High-grade amphibolite, metasedimentary rocks, and metaserpentinite also are found $55 \mathrm{~km}$ to the south in the Marble Mountain terrane (Blake and others, 1982).

\section{STRUCTURAL GEOLOGY}

The May Creek Schist displays a strong northeasttrending, southeast-dipping foliation defined by compositional layering (metamorphic segregation possibly reflecting original sedimentary layering) and by planar alignment of micas. This trend is parallel to the regional northeast-trending grain of the northernmost Klamath Mountains. In volcanic metagraywackes, plagioclase- and amphibole-rich layers, possibly reflecting original sedimentary layering in a tuffaceous protolith, impart a measurable foliation. The foliation is also defined by flattened lensoidal plagioclase, hornblende, or biotite clusters. The pole to the best-fit great circle for 123 foliation readings in the May Creek Schist plunges $32^{\circ} \mathrm{S} .25 \mathrm{E}$. Linear features are generally weakly developed except near a ductile shear zone at the base of the unit (described below), where thinly laminated micaceous quartzites show a striking lineation manifested by fine striations within the foliation plane. Close examination reveals elongated quartz, feldspar, and mica grains. The mean lineation vector for 31 stretching and intersection lineation measurements, including those measured in the ductile shear zone, plunges $26^{\circ} \mathrm{S} .45 \mathrm{E}$.

No measurable folds were observed in outcrops of the May Creek Schist, but stream boulders and float blocks clearly show isoclinally folded layering. In at least one of these cases, a lineation caused by intersection of compositional layering (originally bedding?) with axialplanar cleavage was parallel to the fold axis. 
The amphibolite underlying the May Creek Schist is an L-S tectonite with a pervasive schistosity or foliation defined by alternating hornblende- and plagioclase-rich layers. The foliation generally strikes northeast and dips southeast, parallel to that of the May Creek Schist. The pole to the best-fit great circle for 134 foliation readings in the amphibolite plunges $31^{\circ}$ S. 22 E. A strong, consistent, southeast-plunging hornblende lineation is also present throughout the area. The mean lineation vector for 92 hornblende lineation measurements plunges $31^{\circ}$ S. $38 \mathrm{E}$.
Rare outcrop-scale isoclinal reclined folds (Class 2, similar folds of Ramsay, 1967) deform the compositional layering in the amphibolite. Assuming the layering is metamorphic segregation layering formed during an early phase of deformation, the observed folds are at least second-generation $\left(\mathrm{F}_{2}\right)$. However, no refolded fold hinges were observed. Available data indicate that the folds generally plunge southeast, parallel to the hornblende lineation and parallel to stretching lineations measured in the May Creek Schist within the ductile shear zone; the

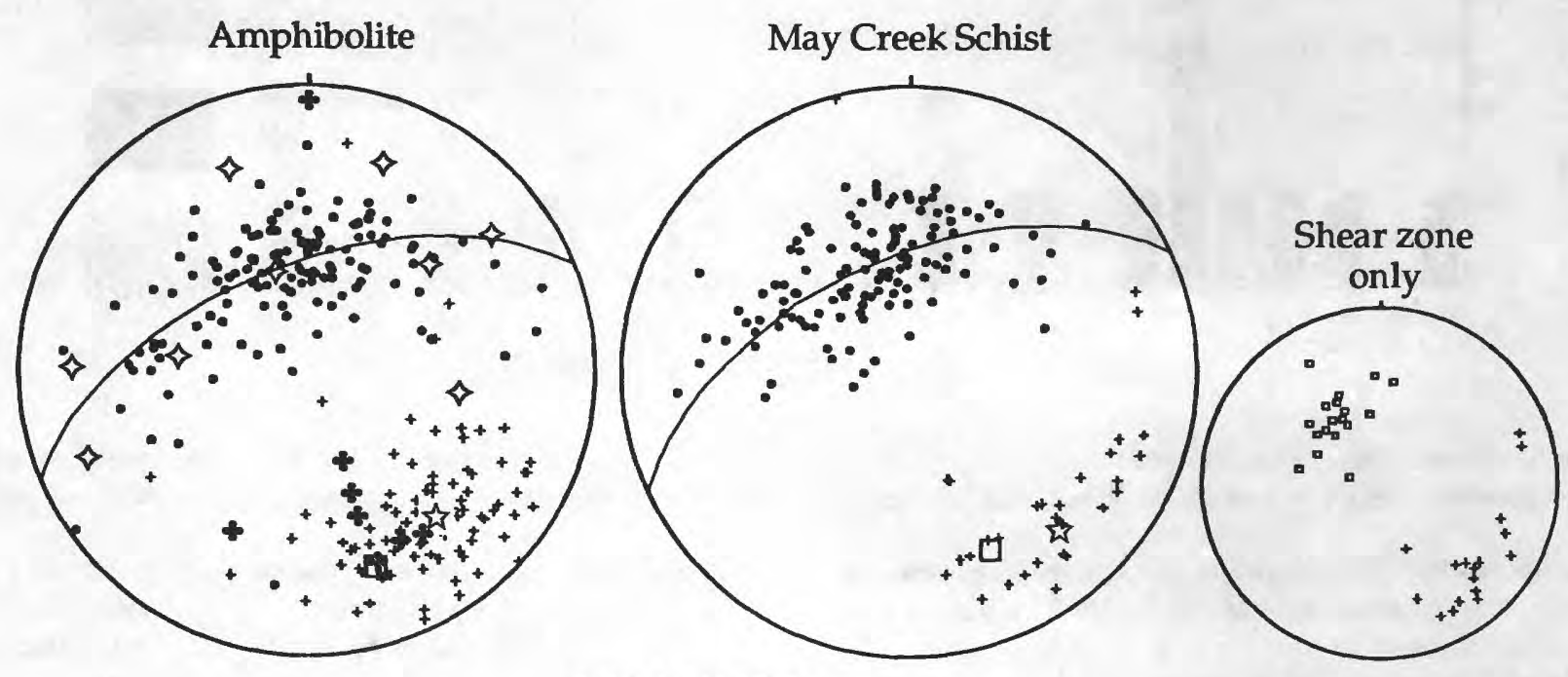

EXPLANATION

- Pole to foliation

- Lineation

- Fold axis

$\diamond$ Pole to axial plane

Pole to best-fit great circle

Mean lineation vector

\begin{tabular}{ccc} 
Awwhibulite May Crask Sclust & Shearzons \\
\hline \multicolumn{3}{c}{ Number of measurements } \\
\hline 134 & 123 & 18 \\
9 & 31 & 17 \\
9 & &
\end{tabular}

\begin{tabular}{cc} 
& Azimuth and plunge \\
\hline 158,31 & 155,32 \\
142,31 & 135,26
\end{tabular}

Figure 5. Equal-area stereographic projections of all measured foliations and lineations in May Creek Schist and in amphibolite. Small stereogram at lower right shows only measurements taken within ductile shear zone. $n$, number of samples

axial planes of reclined folds are parallel to the measured foliation.

Structures in the amphibolite and in the May Creek Schist are parallel and suggest that the two units were contemporaneously deformed (fig. 5). Poles to foliations in both the May Creek Schist and the amphibolite form overlapping broad girdles indicating gentle folding about southeast-plunging axes. Hornblende lineations and stretching lineations from the ductile shear zone overlap equally well, and although there is considerable scatter in the data, the mean vectors coincide very closely. Fold axial planes are widely scattered and data are few; nonetheless, they fall in the same broad girdle with the foliation data, suggesting they too were gently warped.
Limited data for fold axes generally coincide with, but dó not entirely mimic, all lineations.

A wide zone of ductile deformation marks the contact between the May Creek Schist and the underlying amphibolite (Donato, 1990). Mylonitic textures (including reduced grain size, extreme flattening, and strong lineation) are observed in a zone 800 to $1,500 \mathrm{~m}$ thick and are best developed in the quartzofeldspathic lithologies near the base of the May Creek Schist east of the Wimer pluton. Similar and presumably correlative mylonitic schists have also been mapped west of the Wimer pluton, but definite shear sense criteria were not found there. Strongly sheared, fault-bounded, lensoidal serpentinite bodies also are found within the contact zone. Stretching 
lineations in the ductilely deformed rocks are generally parallel to hornblende lineations measured in the amphibolite. Petrofabric evidence and textural shear criteria in oriented samples of quartz-mica schist and quartzofeldspathic gneiss from within the shear zone indicate northwestward thrusting of the May Creek Schist over the amphibolite (Donato, 1990). The age of this thrusting is presumed to be Late Jurassic (Nevadan), on the basis of the apparent synchroneity of deformation and metamorphism.

\section{DESCRIPTION OF MAP UNITS}

\section{SEDIMENTARY ROCKS}

Tpv Pyroclastic and volcaniclastic rocks (Oligocene)-Coarse- to fine-grained rocks of volcanic, volcaniclastic, and sedimentary origin. Also includes minor pyroxene gabbro

Wh Hornbrook Formation (Early Cretaceous)Brown- to buff-weathering, medium-grained sandstone, conglomerate, and siltstone (see Peck and others, 1956; Sliter and others, 1984). Equivalent to the Grave Creek strata of Jones (1960). A conglomerate interval near Ditch Creek contains 2-to 3 -in. cobbles of granitic rocks, metamorphic rocks, and serpentinite

\section{METAMORPHIC ROCKS}

\author{
Western Paleozoic and Triassic belt \\ May Creek terrane of Silberling and others (1987) and \\ Irwin (in press)
}

mc May Creek Schist (Jurassic or older; protolith age)-Foliated and locally lineated metasedimentary rocks. Lower structural levels consist of fine- to medium-grained quartzite, slaty quartzite, phyllite, and quartzmica-plagioclase-garnet schist. Greenishbrown tourmaline is a characteristic accessory mineral visible in thin section. Minor amounts of sillimanite seen in a few metapelitic samples may be of contact-metamorphic origin. Volumetrically minor but widespread calcareous intervals, including rare, grayishwhite marble pods and quartz-diopsideclinozoisite-calcite-tremolite/actinolite schist also are found. Locations of calcareous rocks are shown by overlay patterns on the geologic map. Deeply-colored pink sphene, pleochroic in thin section, is a common accessory mineral in the calcareous rocks. At higher structural levels, the quartzose rocks grade into volcanogenic metasedimentary rocks, including tuffaceous mafic metasandstone and metasiltstone and feldspar-rich metagraywacke. Metamorphic hornblende and (or) biotite pseudomorphs commonly replace detrital pyroxene in the more mafic graywackes. Amphibolite-facies metamorphic grade is indicated by quartz-plagioclasegarnet-biotite assemblage in metapelites, by hornblende-plagioclase in mafic metasedimentary rocks, and by calcitediopside-tremolite-quartz in calcareous rocks. Rocks are locally contact metamorphosed (shown by dot pattern) by granitic plutons, as evidenced by presence of lumps of micaceous material replacing former andalusite porphyroblasts in shaley intervals. Unit is considered to be Jurassic or older in age (protolith) based on similarity in metamorphic grade and structural history to amphibolite (unit am) ; metamorphic age is considered to be Late Jurassic

am Amphibolite (Jurassic or older) - Dark-gray to greenish-gray, foliated and lineated, hornblende-plagioclase schist and gneiss containing accessory sphene or rutile, opaque oxides, and minor local epidote. Minor metapelitic intervals are found high in the structural section. Mineral assemblages indicate amphibolite-facies metamorphic grade. Metamorphic age is $145 \mathrm{Ma}$ as determined from ${ }^{40} \mathrm{Ar} /{ }^{39} \mathrm{Ar}$ analysis on hornblende. In less strongly deformed areas, textural features indicating igneous protoliths are preserved in spite of thorough metamorphic recrystallization. Igneous textures include unaligned to subparallel 0.5to $1.5-\mathrm{cm}$ plagioclase laths interpreted as relict plagioclase phenocrysts, hornblende pseudomorphs of 3 to $5 \mathrm{~mm}$, equant grains suggesting former clinopyroxene phenocrysts, and chilled contacts between concordant to discordant metamorphosed dikes and sills. The following textural varieties were recognized in the field, but were not mappable as separate units. Areas where these textural varieties were observed are designated by overlay patterns within unit am:

Metagabbro-Discontinuous concordant bodies 2- to 5 m-thick of coarse-grained, locally pegmatitic, massive to gneissic hornblendeplagioclase rocks. Contains hornblende and plagioclase grains and clusters of grains as long as $1.5 \mathrm{~cm}$. Clinopyroxene forms cores of some hornblende grains

Hornblende metadiorite and metadiabase-Fine- to medium-grained, massive, equigranular hornblende-plagioclase rocks. Forms irregular plutons or $1-$ to $2-\mathrm{m}$ wide dikes or sills with relict chilled margins. Characterized by subophitic to intergranular textures in hornblende and plagioclase

Porphyritic metadiabase-Fine- to mediumgrained metadiabase characterized by unaligned to sub-parallel $0.5-$ to $2-\mathrm{cm}$ plagioclase laths in a finer-grained matrix. In thin section some plagioclase laths retain albite twin lamellae and oscillatory zoning, thus supporting an igneous origin. Hornblende pseudomorphs of 3- to $5-\mathrm{mm}$ equant grains suggesting former clinopyroxene phenocrysts are also present in some cases 
msp Metaserpentinite (Jurassic or older)-Massive to schistose, fault-bounded bodies of metamorphosed serpentinite ranging in size from a few meters to $2 \mathrm{~km}$ in longest dimension. Composed of antigorite, tabular to elongate olivine, tremolite-actinolite, magnetite, and chlorite. Mineral assemblage indicates metamorphism to amphibolite facies. One sample from the body located near Sprignett Creek contains the $\mathrm{met}$ a $\mathrm{m}$ or $\mathrm{ph}$ assemblage: olivine+clinopyroxene+orthopyroxene+chlorite +green spinel+opaque, indicating pyroxenehornfels or granulite-facies conditions. Many small bodies are present as fault-bounded silvers are not shown at the scale of this map

Western Jurassic belt

Rogue River subterrane (of the western Klamath terrane)

Jmsu Mafic schist and siliceous metasedimentary rocks, undivided (Jurassic?)Predominantly greenish-gray foliated actinolite-chlorite-epidote schist. Locally includes interlayered crenulated siliceous graphitic schist and slate. Mineral assemblages indicate lower greenschist facies, but amphibolite-facies mafic schists are found near the White Rock pluton and the pluton near Tombstone Gap. Distinguished from amphibolite (unit am) by presence of interlayered graphitic schist, by lower metamorphic grade, and by different deformational style

Jmt Metamorphosed tuffaceous sedimentary rocks (Jurassic?) - Pale-green to greenishgray, fine-grained, thinly layered fissile schist. Minor greenish-gray, platy shale and phyllite. Consists mainly of actinolite, chlorite, epidote, and albite. Accessory pyrite cubes found locally. Mineral assemblage indicates greenschist-facies metamorphic grade. Tuffaceous origin for unit is indicated by local millimeter- to centimeter-scale layering and by detrital plagioclase and pyroxene (now pseudomorphed by albite and actinolite, respectively). Tuffaceous schist is locally intruded by small metamorphosed diabase intrusive bodies (not shown on geologic map). Numerous fault-bounded, sheared, and metasomatized serpentinite bodies ranging from a few meters to hundreds of meters in longest dimension also are present. Faulting, fracturing, and quartz veining are common

J'gs Greenstone (Jurassic?)- Massive, locally sheared, greenish, basic, metavolcanic material consisting of metamorphosed basalt, agglomerate, volcanic breccia, and gabbro. Locally includes pale-green to white metachert, cherty tuff, and slaty tuff. Greenschist-facies metamorphism is evidenced by albite, actinolite, chlorite, and epidote. Unaltered relict igneous clinopyroxene is common
JsI Slate and phyllite (Jurassic?)- Thinly laminated, fissile, black to gray slate and phyllite

Jsp Serpentinite (Jurassic?)-Serpentinite bodies composed mainly of antigorite, chrysotile, and minor magnetite. Accessory chromite observed locally. Predominance of antigorite indicates greenschist-facies metamorphic facies. Bodies range in size from a few meters to $7 \mathrm{~km}$ in longest dimension

\section{INTRUSIVE ROCKS}

Biotite-hornblende leucotonalite to granodiorite (Early Cretaceous)-Mediumto coarse-grained, massive, light-colored, intrusive rocks containing quartz, plagioclase, biotite, hornblende, and accessory sphene and opaque oxides. Forms the White Rock pluton. The smaller intrusive body near Tombstone Gap is similar in mineralogy and consists of leucocratic, coarse-grained biotite-hornblende tonalite to granodiorite with minor potassium feldspar and white mica. Analyzed samples contain about 67 to 72 percent $\mathrm{SiO}_{2}, 0.8$ to 3.2 percent $\mathrm{MgO}$ + total iron as $\mathrm{Fe}_{2} \mathrm{O}_{3}$ and 0.6 to 1.6 percent $\mathrm{K}_{2} \mathrm{O}$. $\mathrm{K}-\mathrm{Ar}$ age determination on biotite from the White Rock pluton is $141 \mathrm{Ma}$ (Hotz, 1971)

Kqd Hornblende-biotite quartz diorite (Early Cretaceous?)-Medium-grained, foliated to massive, plutonic rocks composed of plagioclase, quartz, biotite, hornblende, and in some cases, potassium feldspar. Accessory sphene and apatite are common. Forms the Wimer pluton and the smaller unnamed pluton north of Bald Mountain. Age uncertain, but may be Cretaceous based on lithologic similarity to the Grants Pass pluton, $10 \mathrm{~km}$ to the west, whose age was determined to be 139 $\mathrm{Ma}$ by $\mathrm{U} / \mathrm{Pb}$ (zircon) method (Saleeby, 1984). Analyzed samples contain about 59 to 65 percent $\mathrm{SiO}_{2}, 7$ to 11 percent $\mathrm{MgO}+$ total iron as $\mathrm{Fe}_{2} \mathrm{O}_{3}$, and 1.5 to 3 percent $\mathrm{K}_{2} \mathrm{O}$

Jdqd Diorite and quartz diorite (Late Jurassic?)-Medium- to coarse-grained, foliated to gneissic, plutonic bodies about 500 $m$ in diameter. Larger bodies probably exist but their boundaries are difficult to map because of metamorphism and deformation. Small plutons exposed in the West Fork of Evans Creek and in roadcuts above the creek contain plagioclase ( \pm quartz), brownish-green ovate or lenticular hornblende (commonly with green rims), sphene, and opaque oxides. These rocks are considered pretectonic or syntectonic in origin, based on presence of deformation features such as locally developed, outcrop-scale, ductile shear bands which indicate high-temperature plastic flow, and petrographic criteria such as incipient S-C fabrics, bending and kinking of quartz and feldspar, and metamorphic overgrowths of igneous amphiboles. Although there is no direct petrographic evidence of magmatic- 
state deformation, it is possible that these rocks were intruded during early phases of deformation and cooled below their solidi as deformation proceeded

Quartz anorthosite (Jurassic or older)Medium- to coarse-grained, foliated to massive, gray, plutonic rocks forming a small pluton east-northeast of Sprignett Butte. Plagioclase, quartz, dark-bluish-green hastingsitic amphibole (composition confirmed by microprobe analysis), sphene, and emerald-green clinopyroxene (probably aegirene-augite) were identified in thin section. Interpreted as pretectonic or syntectonic in origin based on bent and kinked twin lamellae in plagioclase, strong undulose extinction and recrystallization in quartz, and development of tectonic foliation defined by deformed quartz and plagioclase

\section{REFERENCES CITED}

Blair, W.N., Wong, A., Moring, B.C., Barnard, J.B., Page, N. J, and Gray, F., 1981, Reconnaissance geologic map of parts of the Gold Hill, Ruch, Medford, and Talent 15' quadrangles, southwestern Oregon: U.S. Geological Survey Open-File Report 81-1076, scale 1:62,500.

Blake, M.C., Jr.; Howell, D.G.; and Jones, D.L., 1982, Preliminary tectonostratigraphic terrane map of California: U.S. Geological Survey Open-File Report 82-593, scale 1:750,000.

Diller, J.S., 1914, Mineral resources of southwestern Oregon: U.S. Geological Survey Bulletin 546, 147 p.

Diller, J.S., and Kay, G.F., 1924, Description of the Riddle quadrangle, Oregon: U.S. Geological Survey Atlas, Riddle Folio, No. 218.

Donato, M.M., 1987, The May Creek Schist, southwestern Oregon: remnant of an incipient back-arc basin? [abs.]: Geological Society of America Abstracts with Programs, v. 19, no. 6, p. 373.

1990, A newly-recognized ductile shear zone in the northeastern Klamath Mountains [abs.]: Geological Society of America Abstracts with Programs, v. 22, no. 3, p. 19.

- in press, Geochemistry and tectonic significance of a metabasalt complex of Nevadan age, southwestern Oregon: Journal of Geology, v. 99, no. 5.

Garcia, M.O., 1979, Petrology of the Rogue and Galice Formations, Klamath Mountains, Oregon: identification of a Jurassic island arc sequence: Journal of Geology, v. 87, p. 29-41.

Harper, G.A., and Wright, J.E., 1984, Middle to late Jurassic tectonic evolution of the Klamath Mountains, California-Oregon: Tectonics, v. 3, p. 759-772.

Hawkins, J.W., 1980, Petrology of back-arc basins and island arcs: their possible role in the origin of ophiolites, in Panayiotou, A., ed., Proceedings, International Ophiolite Symposium, Cyprus, Ministry of Agriculture and Natural Resources: Geological Survey Department, Nicosia, Cyprus, p. 244-254.
Hodges, K.V., and Spear, F.S., 1982, Geothermometry, geobarometry, and the $\mathrm{Al}_{2} \mathrm{SiO}_{5}$ triple point at $\mathrm{Mt}$. Moosilauke, New Hampshire: American Mineralogist, v. 271, p. 97-131.

Hotz, P.E., 1971, Plutonic rocks of the Klamath Mountains, California and Oregon: U. S. Geological Survey Professional Paper 684-B, p. B1-B20.

Irwin, W.P., 1966, Geology of the Klamath Mountains province, in Bailey, E.H., ed., Geology of Northern California: California Division of Mines and Geology Bulletin 190, p. 19-38.

1985, Age and tectonics of plutonic belts in accreted terranes of the Klamath Mountains, in Howell, D.G., ed., Tectonostratigraphic terranes of the Circumpacific region: Circumpacific Council for Energy and Mineral Resources, Earth Science Series, No. 1, p. 187-199.

- in press, Geologic map of the Klamath Mountains: U.S. Geological Survey Miscellaneous Investigations Series Map I-2148, scale 1:500,000.

Irwin, W.P., Jones, D.L., and Kaplan, T.A., 1978, Radiolarians from pre-Nevadan rocks of the Klamath Mountains, California and Oregon, in McDougall, K.A., and Howell, D.G., eds., Mesozoic Paleogeography of the western United States: Pacific Coast Paleogeography Symposium 2, p. 303-310.

Jenner, G.A., Cawood, P.A., Rautenschlein, M., and White, W.M., 1987, Composition of back-arc basin volcanics, Valu Fa Ridge, Lau Basin: Evidence for a slab-derived component in their mantle source: Journal of Volcanology and Geothermal Research, v. 32, p. 209 222.

Jones, D.L., 1960, Lower Cretaceous (Albian) fossils from southwestern Oregon and their paleogeographic significance: Journal of Paleontology, v. 34, p. 152-160.

Kays, M.A., 1970, Mesozoic metamorphism, May Creek Schist belt, Klamath Mountains, Oregon: Geological Society of America Bulletin, v. 81, p. 2743-2758.

Page, N.J, Blair, W.N., Gray, F., Cannon, J.K., Grimes, D.J., and Leinz, R.W., 1977, Preliminary reconnaissance geologic map of the Wimer quadrangle, Oregon: U.S. Geological Survey Miscellaneous Field Studies Map MF-848, scale 1:62,500.

Pearce, J.A., and Cann, J.R., 1973, Tectonic setting of basic volcanic rocks determined using trace element analyses: Earth and Planetary Science Letters, v. 19, p. 290-300.

Pearce, J.A., and Norry, M.J., 1979, Petrogenetic implications of $\mathrm{Ti}, \mathrm{Zr}, \mathrm{Y}$, and $\mathrm{Nb}$ variations in volcanic rocks: Contributions to Mineralogy and Petrology, v. 69, p. 33-47.

Peck, D.L., Imlay, R.W., and Popenoe, W.P., 1956, Upper Cretaceous rocks of parts of southwestern Oregon and northern California: American Association of Petroleum Geologists Bulletin, v. 40, p. 1968-1984.

Ramsay, J.G., 1967, Folding and fracturing of rocks, 568 p., McGraw-Hill, New York. 
Saleeby, J.B., 1984, $\mathrm{Pb} / \mathrm{U}$ zircon ages from the Rogue River area, western Jurassic belt, Klamath Mountains, Oregon [abs.]: Geological Society of America Abstracts with Programs, v. 16, p. 331.

Saunders, A.D., and Tarney, J., 1979, The geochemistry of basalts from a back-arc spreading centre in the East Scotia Sea: Geochimica et Cosmochimica Acta, v. 43, p. 555-572.

Silberling, N.J., Jones, D.L., Blake, M.C. Jr., and Howell, D.G., 1987, Lithotectonic terrane map of the western conterminous United States: U.S. Geological Survey Miscellaneous Field Studies Map MF-1874-C, scale $1: 2,500,000$.

Sinton, J.M., and Fryer, P., 1987, Mariana Trough lavas from $18^{\circ} \mathrm{N}$ : Implications for the origin of back arc basin basalts: Journal of Geophysical Research, v. 92, p. 12,782-12,802.

Sliter, W.V., Jones, D.L., and Throckmorton, C.K., 1984, Age and correlation of the Cretaceous Hornbrook Formation, California and Oregon, in Nilsen, T. H., ed., Geology of the Upper Cretaceous Hornbrook Formation, Oregon and California: Pacific Section, Society of Economic Paleontologists and Mineralogists, no. 42, p. 89-98.

Smith, J.G., Page, N.J, Johnson, M.G., Moring, B.C., and Gray, F., 1982, Preliminary map of the Medford $1^{\circ} \times 2^{\circ}$ sheet, Oregon, U.S. Geological Survey Open-File Report 82-955, scale 1:250,000.
Walker, G.W. and MacLeod, N.S., in press, Geologic map of Oregon: U. S. Geological Survey, scale 1:500,000, 2 sheets.

Wardlaw, B.R., and Jones, D.L., 1979, Triassic conodonts from eugeoclinal rocks of western North America and their tectonic significance: Rivista Italiana de Paleontologia e Stratigrafia, v. 85, no. 3-4, p. 895-908.

Wells, F.G., 1955, Preliminary geologic map of southwestern Oregon west of meridian $122^{\circ}$ west, and south of parallel $43^{\circ}$ north: U. S. Geological Survey Miscellaneous Field Studies Map MF-38, scale 1:250,000.

Wells, F.G., Hotz, P.E., and Cater, F. W., 1949, Preliminary description of the geology of the Kerby Quadrangle, Oregon: State of Oregon Department of Geology and Mineral Industries, Bulletin No. 40, 23 p.

Wells, F.G., and Waters, A. C., 1934, Quicksilver deposits of southwestern Oregon: U. S. Geological Survey Bulletin 850, $58 \mathrm{p}$.

Wells, F.G., and Peck, D.L., 1961, Geologic map of Oregon west of the 121st meridian: U.S. Geological Survey Miscellaneous Investigations Series Map I-325, scale 1:500,000.

Wood, D.A., 1980, The application of a Th-Hf-Ta diagram to problems of tectonomagmatic classification and to establishing the nature of crustal contamination of basaltic lavas of the British Tertiary Province: Earth and Planetary Science Letters, v. 50, p. 11-30. 